
\title{
3 Research Square \\ Selected risk factors of dental caries in 11- to 13- years old schoolchildren in Slovakia
}

\section{Eliska Stefanova}

Univerzita Komenskeho v Bratislave Jesseniova Lekarska Fakulta v Martine

\section{Tibor Baska}

Univerzita Komenskeho v Bratislave Jesseniova Lekarska Fakulta v Martine

Jana Holubcikova

Univerzita Pavla Jozefa Safarika v Kosiciach Lekarska fakulta

Silvia Timkova ( $\nabla$ savan@no-name.sk)

Univerzita Pavla Jozefa Safarika v Kosiciach Lekarska fakulta

\section{Maria Tatarkova}

Univerzita Komenskeho v Bratislave Jesseniova Lekarska Fakulta v Martine

\section{Miroslava Sovicova}

Univerzita Komenskeho v Bratislave Jesseniova Lekarska Fakulta v Martine Henrieta Hudeckova

Univerzita Komenskeho v Bratislave Jesseniova Lekarska Fakulta v Martine

\section{Research article}

Keywords: risk factors of caries, oral health, dental hygiene, adolescents

Posted Date: November 21st, 2019

DOI: https://doi.org/10.21203/rs.2.17580/v1

License: (c) (1) This work is licensed under a Creative Commons Attribution 4.0 International License.

Read Full License 


\section{Abstract}

Background: Oral diseases, particularly dental caries, affect as much as 9 in 10 persons globally. Its development starts during childhood and among factors participating in its aetiology, behavioural ones play a particularly important role. The aim of the study was to examine the selected behavioural risk factors of dental caries in Slovak adolescents between 2006 and 2018.

Methods: We analysed occurrence of the selected factors (teeth brushing less than once a day, eating sweets and drinking sweetened soft drinks daily and their combination) in 11 to 13 years old schoolchildren in Slovakia by gender and socio-economic status using data from Health Behaviour in School-Aged Children surveys carried out in 2005/2006, 2009/2010, 2013/2014 and 2017/2018.

Results: Consumption of sweets and sweetened soft drinks, despite of decline, remains widespread ( $41.3 \%$ of boys and $39.6 \%$ of girls in $2017 / 2018$ ). Absence of daily teeth brushing, similarly as cooccurrence of these two risk factors, were more frequent in boys $(10.6 \%$ and $5.0 \%$ in $2017 / 2018$, respectively) than in girls (5.1\% and $2.3 \%$ in $2017 / 2018$, respectively). Absence of daily teeth brushing was associated with lower socioeconomic situation.

Conclusions: Behavioural risk factors of dental caries play significant role in oral health of adolescents in Slovakia. Despite positive development of the epidemiological situation, effective interventions focused on consumption of sweets and sweetened soft drinks as well as improvement of oral hygiene in lower socioeconomic groups are needed.

\section{Background}

Oral health is defined as a normal state of oral cavity with individual's ability to eat, smile, and speak, etc. without pain of any kind or noticeable disease [1]. Oral health along with appropriate dental hygiene is very important for maintaining overall health [2].

Dental caries ranks among the most common oral diseases [3]. Nature of the caries is gradual and cumulative. With time it becomes more compound. Due to its prevalence, economic aspects and effect on quality of life it is a significant public health problem [4-6].

Untreated caries in children may negatively affect their quality of life in many ways. Besides direct negative impact i.e. pain, troubles in eating, it is the most frequent cause of loss of teeth. Consequences of dental caries have a lifetime effects including decreased quality of life, impaired self-esteem, as well as can result in various chronic diseases [7].

According to official World Health Organization (WHO) data, prevalence of tooth decay among 6 years old children in European countries considerably varies between 20 to 90 per cent [1]. In general, relatively positive situation can be seen in Western and Northern Europe such as United Kingdom or Scandinavian countries. On the other hand, the highest prevalence is in Eastern Europe. To monitor dental health, DMFT 
index is widely used as an epidemiological tool indicating count of decayed (D), missing (M) and filled (F) teeth $(T)[8,9]$. Slovakia, together with Croatia ranks among countries with the highest average DMFT index (4.3 and 4.8, respectively) within the European Union member countries [8,10-13]. However, we should keep in mind that above mentioned information is mostly based on data coming from dentists providing primary dental care. So, these estimations originate from population attending dentists for treatment or/and preventive check-up and there are insufficient epidemiologic data from those not attending dentists. Therefore, population representative data would bring light to better understand an extent of the issue.

There are numerous factors increasing a risk of the dental caries. Beside inherent and metabolic predisposition, behavioural risk factors are of a great importance. Among them, namely oral hygiene and diet play a significant role $[1,8,14]$. Teeth brushing applied at least once a day has been considered as a principal tool to maintain oral health and to prevent caries and periodontal diseases [15]. On the other hand, consumption of sweetened food, soft and energy drinks promote initiation and further development of dental caries [16].

Numerous recent studies indicate that a socioeconomic situation can be considered as an independent determinant of teeth decay. Higher consumption of soft drinks was detected in children from low socioeconomic families and whose teeth brushing was sporadic [17-19]. It is also confirmed that children with good oral hygiene have mothers with higher education level $[20,21]$. Significantly more cases of dental caries are present in children whose grow up in lower socioeconomic families, in combination with low income and low education level [22].

Age of 12 is internationally determined as an age for global monitoring of dental caries. It is mostly because in majority of children all the permanent teeth have already erupted (except third molars) [13]. Considering the long-term and even lifelong impact of the caries, age between 11 to 13 years is crucial. Therefore, factors triggering process of caries and its further development are of a particular importance during this period. Understating of epidemiological aspects of risk factors of caries during childhood can considerably help to design and implement effective preventive intervention programs tailored for this target population.

In our study, we focused on selected indicators of insufficient dental hygiene (teeth brushing less than once a day) and eating habits associated with increased risk of caries (eating sweets daily, drinking soft drinks daily and their combination) among 11 to 13-years old children. We used data of the Health Behaviour in School-Aged Children (HBSC) surveys carried out in Slovakia in 2005/2006, 2009/2010, $2013 / 2014$ and $2017 / 2018$. The goals of the study include estimation of prevalence of children population in Slovakia in increased risk of caries analysed by gender and socioeconomic status as well as to identify trends over time. Results of our study, based on valid representative epidemiological data, can contribute to better understand the issue as such, to estimate prevalence of children population at risk considering basic sociodemographic determinants. Moreover, our findings can provide a basis to better identify target population groups for effective tailored preventive measures. 


\section{Methods}

Health Behaviour in School aged Children is an international, school-based cross-sectional study. Its standardised design enables to create harmonized datasets appropriate for cross-country comparisons as well as for identifying changes over time. Data are collected through uniform anonymous questionnaires filled out in classes at schools.

The sample is created in accordance with structure of the educational system in the given country and is stratified by region and type of school in order to obtain representative data from 11 to 15-year-old adolescents.

In Slovakia, four HBSC surveys have been carried out: in school years 2005/2006, 2009/2010, 2013/2014 and 2017/2018, data has been collected in May-June 2006, 2010, 2014 and 2018. Two-step sampling was used keeping the standardized research protocol. In the first step, participating schools were randomly selected with probability proportional to size using an official list of all schools obtained from the Slovak Institute of Information and Prognosis for Education. The sample of schools was stratified by region (eight administrative self-governing regions) and type of school (elementary schools comprising the $1^{\text {st }} 9^{\text {th }}$ grades, and eight-year grammar schools comprising the $6^{\text {th }}-13^{\text {th }}$ grades). In the second step, within the participating schools, classes were randomly selected to collect data. Parents were informed in advance about the study via the school administration and using a written informed consent form could opt out if they disagreed with their child's participation. Participation in the study was fully voluntary and anonymous, with no explicit incentives provided for participation. This approach provided samples proportionally representing all areas and population subgroups on the nationwide level and thus eliminating possible bias caused by heterogeneity of the target population. Pupils from the $5^{\text {th }}-9^{\text {th }}$ grades were considered as eligible, i.e. associated with 11- to 15-year-old adolescents. We included 11 to 13years old respondents in our analysis.

Table 1 Characteristic of the samples of HBSC surveys 


\begin{tabular}{|l|c|c|c|c|}
\hline & $\begin{array}{c}\text { Number of schools } \\
\text { involved in the survey }\end{array}$ & $\begin{array}{c}\text { Total number of } \\
\text { respondents }\end{array}$ & $\begin{array}{c}\text { Response } \\
\text { rate }\end{array}$ & $\begin{array}{c}\text { Number of } 11 \text { to 13-years old } \\
\text { respondents (boys) }\end{array}$ \\
\hline $2005 / 2006$ & 87 & 3877 & $85,60 \%$ & $2525(1203)$ \\
\hline $2009 / 2010$ & 106 & 4308 & $79,50 \%$ & $2740(1302)$ \\
\hline $2013 / 2014$ & 130 & 5245 & $78,80 \%$ & $3696(1811)$ \\
\hline $2017 / 2018$ & 109 & 8902 & $60,00 \%$ & $5260(2651)$ \\
\hline
\end{tabular}

Table 1 shows the basic characteristic of the samples obtained in four waves of the survey. Drop outs were caused mostly by the absence of children due to illness or other personal reasons and the refusal of a parent or the adolescent to be involved in the study.

Our study analyses prevalence of insufficient teeth brushing (less than once a day), eating of sweets and/or drinking of sweetened soft drinks, co-occurrence of the two above mentioned factors in relation to gender and socioeconomic status:

- Teeth brushing was measured by the question "How often do you brush your teeth? Possible responses were "More than once a day", "Once a day", "At least once a week but not daily", "Less than once a week" and "Never". After dichotomisation, we analysed proportion of answers "At least once a week but not daily", "Less than once a week" and "Never".

- Consumption of sweets in schoolchildren was measured by the question "How many times a week do you usually eat sweets (candy or chocolate)?" Possible answers were "Never", "Less than once a week", "Once a week", "2-4 days a week", "5-6 days a week", "Once a day every day" and "Every day, more than once". After dichotomisation, we analysed proportion of answers "Once a day every day" and "Every day, more than once".

- Consumption of sweetened soft drinks was measured by question "How many times a week do you usually drink coke or other soft drinks that contain sugar". Possible answers were "Never", "Less than once a week", "Once a week", "2-4 days a week", "5-6 days a week”, "Once a day every day" and "Every day, more than once". We analysed proportion of answers "Once a day every day" and "Every day, more than once".

- Socioeconomic status of family is in HBSC research defined by Family Affluence Scale (FAS) which consists of four questions: "Does your family own a car, van or truck" (No $=0$, Yes, one $=1$, Yes, two or more = 2), "Do you have your own bedroom for yourself?" (No = 0, Yes $=1)$, "How many computers does your family own?" (None $=0$, One $=1$, Two $=2$, More than two $=3$ ), "How many times did you and your family travel out of Slovakia for a holiday/vacation last year?" (Not at all $=0$, Once $=1$, Twice $=2$, More than twice $=3$ ). In the 2014 HBSC data collection, FAS was updated and two more questions were added to this instrument: "How many bathrooms (room with a bath/shower or both) 
are in your home?" (None $=0$, One $=1$, Two $=2$, More than two $=3$ ), "Does your family have a dishwasher at home?" (No = 0 , Yes $=1)$. The final score of every respondent determines the socioeconomic status (low SES < median $<$ high SES).

The results are expressed as percentage (\%) with the respective $95 \%$ confidence intervals. Differences were statistically evaluated using Chi-square test. As a level of statistical significance, $p<0.05$ was considered. To test changes across time, Bonferroni correction was applied for post-hoc pairwise comparisons.

\section{Results}

Table 2 Prevalence of selected risk factors of caries in 11-13 years old children

\begin{tabular}{|c|c|c|c|c|c|c|c|}
\hline & & \multicolumn{2}{|c|}{$\begin{array}{l}\text { Absence of } \\
\text { daily teeth } \\
\text { brushing }\end{array}$} & \multicolumn{2}{|c|}{$\begin{array}{l}\text { Daily consumption of } \\
\text { sweets and/or } \\
\text { sweetened soft drinks }\end{array}$} & \multicolumn{2}{|c|}{$\begin{array}{l}\text { Co-occurring of daily teeth brushing } \\
\text { absence with consumption of sweets } \\
\text { and/or sweetened soft drinks }\end{array}$} \\
\hline & & $\begin{array}{l}\text { Abs. } \\
(\%)\end{array}$ & Sign. & Abs. (\%) & Sign. & Abs. (\%) & Sign. \\
\hline \multirow[t]{2}{*}{$2005 / 2006$} & Boys & $\begin{array}{l}145 \\
(12.1)\end{array}$ & \multirow[t]{2}{*}{$p<0.001$} & $696(57.9)$ & \multirow[t]{2}{*}{$p=0.951$} & $85(7.1)$ & \multirow[t]{2}{*}{$p<0.001$} \\
\hline & Girls & $\begin{array}{l}86 \\
(6.0)\end{array}$ & & $821(57.7)$ & & $49(3.4)$ & \\
\hline \multirow[t]{2}{*}{$2009 / 2010$} & Boys & $\begin{array}{l}203 \\
(9.4)\end{array}$ & \multirow[t]{2}{*}{$p<0.001$} & $\begin{array}{l}1141 \\
(52.6)\end{array}$ & \multirow[t]{2}{*}{$p=0.399$} & $102(4.7)$ & \multirow[t]{2}{*}{$p<0.001$} \\
\hline & Girls & $\begin{array}{l}108 \\
(4.6)\end{array}$ & & $\begin{array}{l}1278 \\
(53.9)\end{array}$ & & $53(2.2)$ & \\
\hline \multirow[t]{2}{*}{$2013 / 2014$} & Boys & $\begin{array}{l}187 \\
(7.0)\end{array}$ & \multirow[t]{2}{*}{$p<0.001$} & $\begin{array}{l}1142 \\
(42.7)\end{array}$ & \multirow[t]{2}{*}{$p=0.071$} & $85(3.2)$ & \multirow[t]{2}{*}{$p=0.001$} \\
\hline & Girls & $\begin{array}{l}98 \\
(3.6)\end{array}$ & & $\begin{array}{l}1229 \\
(45.2)\end{array}$ & & $49(1.8)$ & \\
\hline \multirow[t]{2}{*}{$2017 / 2018$} & Boys & $\begin{array}{l}280 \\
(10.6)\end{array}$ & \multirow[t]{2}{*}{$p<0.001$} & $\begin{array}{l}1096 \\
(41.3)\end{array}$ & \multirow[t]{2}{*}{$p=0.196$} & $133(5.0)$ & \multirow[t]{2}{*}{$p<0.001$} \\
\hline & Girls & $\begin{array}{l}132 \\
(5.1)\end{array}$ & & $\begin{array}{l}1033 \\
(39.6)\end{array}$ & & $61(2.3)$ & \\
\hline
\end{tabular}

Within the analysed factors, daily consumption of sweets and/or sweetened soft drinks was widespread affecting a considerable proportion of children (ranking from $57.9 \%$ of boys in $2005 / 2006$ to $39.6 \%$ of girls in 2017/2018). Absence of daily teeth brushing uniformly dominated in boys through the studied period and varied from $10.6 \%$ (boys in $2017 / 2018$ ) to $3.6 \%$ (girls in $2013 / 2014$ ). Dominance of boys was 
projected also in a co-occurrence of insufficient teeth brushing with consumption of sweets and/or sweetened soft drinks and its prevalence was highest in boys in 2005/2006 (7.1\%) (Table 2).

Table 3 Prevalence of selected risk factors of caries by socioeconomic status in 11-13 years old boys

\begin{tabular}{|c|c|c|c|c|c|c|c|}
\hline & & \multicolumn{2}{|c|}{$\begin{array}{l}\text { Absence of } \\
\text { daily teeth } \\
\text { brushing }\end{array}$} & \multicolumn{2}{|c|}{$\begin{array}{l}\text { Daily consumption of } \\
\text { sweets and/or } \\
\text { sweetened soft drinks }\end{array}$} & \multicolumn{2}{|c|}{$\begin{array}{l}\text { Co-occurring of daily teeth brushing } \\
\text { absence with consumption of sweets } \\
\text { and/or sweetened soft drinks }\end{array}$} \\
\hline & & $\begin{array}{l}\text { Abs. } \\
(\%)\end{array}$ & Sign. & Abs. (\%) & Sign. & Abs. (\%) & Sign. \\
\hline \multirow[t]{2}{*}{$2005 / 2006$} & $\begin{array}{l}\text { LoW } \\
\text { FAS }^{1}\end{array}$ & $\begin{array}{l}85 \\
(13.9)\end{array}$ & \multirow[t]{2}{*}{$p<0.05$} & 365 (59.8) & \multirow[t]{2}{*}{$p=0.265$} & $49(8.0)$ & \multirow[t]{2}{*}{$p=0.130$} \\
\hline & $\begin{array}{l}\text { High } \\
\text { FAS }^{2}\end{array}$ & $\begin{array}{l}48 \\
(9.8)\end{array}$ & & $278(56.5)$ & & $28(5.7)$ & \\
\hline \multirow[t]{2}{*}{$2009 / 2010$} & $\begin{array}{l}\text { Low } \\
\text { FAS }^{1}\end{array}$ & $\begin{array}{l}105 \\
(10.6)\end{array}$ & \multirow[t]{2}{*}{$p<0.05$} & $507(51.0)$ & \multirow[t]{2}{*}{$p=0.113$} & $52(5.2)$ & \multirow[t]{2}{*}{$\mathrm{p}=0.161$} \\
\hline & $\begin{array}{l}\text { High } \\
\text { FAS }^{2}\end{array}$ & $\begin{array}{l}67 \\
(7.6)\end{array}$ & & $480(54.7)$ & & $34(3.9)$ & \\
\hline \multirow[t]{2}{*}{$2013 / 2014$} & $\begin{array}{l}\text { LOW } \\
\text { FAS }^{1}\end{array}$ & $\begin{array}{l}95 \\
(7.9)\end{array}$ & \multirow[t]{2}{*}{$p<0.05$} & $500(41.7)$ & \multirow[t]{2}{*}{$p=0.556$} & $45(3.8)$ & \multirow[t]{2}{*}{$p=0.053$} \\
\hline & $\begin{array}{l}\text { High } \\
\text { FAS }^{2}\end{array}$ & $\begin{array}{l}55 \\
(5.2)\end{array}$ & & $458(42.9)$ & & $25(2.3)$ & \\
\hline \multirow[t]{2}{*}{$2017 / 2018$} & $\begin{array}{l}\text { LOW } \\
\text { FAS }^{1}\end{array}$ & $\begin{array}{l}128 \\
(11.7)\end{array}$ & \multirow[t]{2}{*}{$p<0.05$} & $452(41.3)$ & \multirow[t]{2}{*}{$p=0.540$} & $66(6.0)$ & \multirow[t]{2}{*}{$p<0.05$} \\
\hline & $\begin{array}{l}\text { High } \\
\text { FAS }^{2}\end{array}$ & $\begin{array}{l}60 \\
(7.9)\end{array}$ & & $302(39.9)$ & & $22(2.9)$ & \\
\hline
\end{tabular}

${ }^{1}$ Family Affluence Scale up to median

${ }^{2}$ Family Affluence Scale upper median

Table 4 Prevalence of selected risk factors of caries by socioeconomic status in 11-13 years old girls 


\begin{tabular}{|c|c|c|c|c|c|c|c|}
\hline & & \multicolumn{2}{|c|}{$\begin{array}{l}\text { Absence of } \\
\text { daily teeth } \\
\text { brushing }\end{array}$} & \multicolumn{2}{|c|}{$\begin{array}{c}\text { Daily consumption of } \\
\text { sweets or sweetened } \\
\text { soft drinks }\end{array}$} & \multicolumn{2}{|c|}{$\begin{array}{c}\text { Absence of teeth brushing combined } \\
\text { with daily consumption of sweets or } \\
\text { sweetened soft drinks }\end{array}$} \\
\hline & & $\begin{array}{l}\text { Abs. } \\
(\%)\end{array}$ & Sign. & Abs. (\%) & Sign. & Abs. (\%) & Sign. \\
\hline \multirow[t]{2}{*}{$2005 / 2006$} & $\begin{array}{l}\text { LoW } \\
\text { FAS }^{1}\end{array}$ & $\begin{array}{l}60 \\
(7.0)\end{array}$ & \multirow[t]{2}{*}{$p<0.05$} & $507(58.7)$ & \multirow[t]{2}{*}{$p=0.223$} & $36(4.2)$ & \multirow[t]{2}{*}{$p<0.05$} \\
\hline & $\begin{array}{l}\text { High } \\
\text { FAS }^{2}\end{array}$ & $\begin{array}{l}16 \\
(3.4)\end{array}$ & & 261 (55.3) & & $8(1.7)$ & \\
\hline \multirow[t]{2}{*}{$2009 / 2010$} & $\begin{array}{l}\text { LOW } \\
\text { FAS }^{1}\end{array}$ & $\begin{array}{l}74 \\
(5.8)\end{array}$ & \multirow[t]{2}{*}{$p<0.05$} & 689 (53.7) & \multirow[t]{2}{*}{$p=0.808$} & $37(2.9)$ & \multirow[t]{2}{*}{$p=0.054$} \\
\hline & $\begin{array}{l}\text { High } \\
\text { FAS }^{2}\end{array}$ & $\begin{array}{l}25 \\
(2.9)\end{array}$ & & $474(54.2)$ & & $14(1.6)$ & \\
\hline \multirow[t]{2}{*}{$2013 / 2014$} & $\begin{array}{l}\text { LOW } \\
\text { FAS }^{1}\end{array}$ & $\begin{array}{l}58 \\
(4.3)\end{array}$ & \multirow[t]{2}{*}{$p<0.05$} & $644(47.7)$ & \multirow[t]{2}{*}{$p<0.05$} & $28(2.1)$ & \multirow[t]{2}{*}{$p=0.189$} \\
\hline & $\begin{array}{l}\text { High } \\
\text { FAS }^{2}\end{array}$ & $\begin{array}{l}27 \\
(2.5)\end{array}$ & & $461(42.1)$ & & $15(1.4)$ & \\
\hline \multirow[t]{2}{*}{$2017 / 2018$} & $\begin{array}{l}\text { LOW } \\
\text { FAS }^{1}\end{array}$ & $\begin{array}{l}67 \\
(5.6)\end{array}$ & \multirow[t]{2}{*}{$p<0.05$} & $493(40.9)$ & \multirow[t]{2}{*}{$p=0.369$} & $33(2.7)$ & \multirow[t]{2}{*}{$p<0.05$} \\
\hline & $\begin{array}{l}\text { High } \\
\text { FAS }^{2}\end{array}$ & $\begin{array}{l}27 \\
(3.5)\end{array}$ & & $299(38.9)$ & & $7(0.9)$ & \\
\hline
\end{tabular}

\section{${ }^{1}$ Family Affluence Scale up to median}

\section{${ }^{2}$ Family Affluence Scale upper median}

Higher prevalence of insufficient teeth brushing was strongly associated with lower socioeconomic situation holding for both boys and girls (Tables 3, Table 4). Daily consumption of sweets or sweetened soft drinks differed only marginally across socioeconomic groups, except girls in 2013/2014, where those from lower socioeconomic background significantly dominated (47.7 \% vs. $42.1 \%)$. Insufficient teeth brushing combined with consumption of sweets or sweetened soft drinks dominated among respondents from lower socioeconomic groups only in girls in 2005/2006 and both in boys and girls in 2017/2018 (Tables 3, Table 4).

Insufficient teeth brushing prevalence was highest in $2005 / 2006$, including $12.1 \%$ of boys and $6.0 \%$ of girls (Figure 1). It was gradually declining until 2013/2014 both in boys and girls reaching the lowest rate (7.0\% and 3.6\%, respectively). However, the declining trend no longer continued in $2017 / 2018$. It even significantly increased in boys up to $10.6 \%$. 
Almost 6 in 10 respondents reported in 2005/2006 daily consumption of either sweets or sweetened soft drinks (Figure 2). Noticeable declining trend was shown both in boys and girls leading $41.3 \%$ and $35.4 \%$ in $2017 / 2018$, respectively.

Co-occurrence of above-mentioned factors, i.e. insufficient teeth brushing together with daily consumption of sweets or sweetened soft drinks was seen in less than one tenth of the respondents (Figure 3). It showed declining trend until 2013/2014. In 2017/2018, repeated increase was observed, reaching statistical significance only in boys (from $1.8 \%$ to $2.3 \%$ ).

\section{Discussion}

As our results indicate, daily consumption of sugar, despite of declining trend, have remained among the most significant risk factors of dental caries affecting more than one third of schoolchildren aged 11-13 years. This holds both for boys and girls as well as all socioeconomic groups. Worth mentioning is decrease between $2005 / 2006$ and $2017 / 2018$. For boys it was from $57.9 \%(2005 / 2006)$ to less than a half $(41.3 \%$ in $2017 / 2018)$. In girls it was from $57.7 \%$ in $2005 / 2006$ to $35.4 \%$ in $2017 / 2018$.

Insufficient teeth brushing is less common. However, optimistic trend seen until 2013/2014 broke up and according to the last survey carried out in $2017 / 2018$, the situation has returned to be similar those seen in $2005 / 2006$. As the results implicate, this is mostly the issue of boys and lower socioeconomic groups of population. Moreover, about half of those not brushing their teeth also consume sugars on a daily base. Such combination presents a particularly high risk for dental caries. Although present in less than 5 $\%$ of the respondents, we should not underevaluate it. Taking into consideration official statistical population data (162 530 children in age of 11-13 years old up to date of June 30,2018), this problem relates as much as about 8,000 children in Slovakia of this age group [23].

Moreover, we should keep in mind that we deal with subjective data, thus the underreporting can potentially present "a top of iceberg" effect making the problem even deeper [24]. Another problem to be considered is a quality of teeth brushing. As many studies showed, the problem is mostly in wrong technique (incorrect brushing movements, insufficient time of brushing, etc.), which may be in long term harmful to the oral health. Although, this problem is in many cases preventable through proper education [25-29]. Therefore, it is necessary to teach children not only to brush their teeth, but to brush them properly. In this research we only analysed whether or not they brush their teeth. For the future research it could be interesting to deeply analyse determinants of teeth brushing and the quality of teeth brushing techniques.

As already mentioned, the insufficient teeth brushing relates particularly to boys. One of the possible causes may be that women in general consider oral health as important with positive impact on quality 
of life. Also, it could be in the perception of health, which girls seem to receive differently than boys $[30,31]$.

Our results also showed an association between insufficient teeth brushing and socioeconomic situation. Main problem was detected in families with low education of children's parents. Parent, especially mothers, showed up to be very influential in the problematics of creating habits in children [31,32]. However, parents with lower educational level do not place an importance to brushing teeth, probably because of lack of information/health literacy $[5,20]$. Lack of information about oral health in parents is therefore associated with lack of motivation to even teach a child how to brush the teeth or to control if he/she is brushing the teeth. Children are influenced through opinions and attitudes of their parents towards dentists, too. Parental fear and worries about dental care are transferred to children [33]. It is necessary for parents to be motivational factor in the subject of oral hygiene [31,34]. It presents a challenge for public health how to better focus educational and information activities on families with lower socioeconomic position.

As potential limitations of our study, we should consider that the HBSC data do not provide a comprehensive picture on a risk but only some aspects of it. We should consider our findings rather as an insight into the epidemiological situation and its changes over time and trends. These pieces of information, despite their limited scope, provide as important groundwork for population based preventive measures as well as relevant projections of the situation in future. The strongest point of our analysis is, that it uses representative data including the whole target population of the given age group. Most of studies dealing with oral health employ data from dentists $[13,35,36]$. According to the HBSC Slovakia report, as much as $15 \%$ of boys and $12 \%$ of girls aged 13 years reported not visiting the dentists during recent year [37]. Moreover, as the latest official data on dental care show, among children and adolescents ( 6 to 14 years old) as much as one quarter of them have not been registered to dental care $[23,38]$, i.e. such pieces of information are limited to a population attending check-ups and undergoing dental care and can overlook a considerable proportion of the population. Therefore, our findings fulfil this information gap.

\section{Conclusions}

Eventually, despite of decline of the daily eating of sugar within recent years, it remains a widespread risk factor of dental caries in children. Its combination with insufficient teeth brushing is mostly a problem of boys and lower socioeconomic population groups where a particularly high risk can be expected.

Therefore, there is a need to find out effective ways how to address these target groups in preventive programs with emphasis on youngsters when habits are still developing.

\section{List Of Abbreviations}

DMFT-Decayed, Missing, Filled index 
HBSC-Health Behaviour in School-Aged Children

WHO-World Health Organization

\section{Declarations}

\section{Ethics approval and consent to participate}

The study was approved by the Ethics Committee of the Faculty of Medicine at the P.J. Šafárik University in Košice. Parents were informed about the study via the school administration and using a written informed consent form could opt out if they disagreed with their child's participation. Participation in the study was fully voluntary and anonymous, with no explicit incentives provided for participation.

\section{Consent for publication}

Not applicable.

\section{Availability of data and materials}

The dataset supporting the conclusions of this article is available upon request.

\section{Competing interests}

The authors declare that they have no competing interests.

\section{Funding}

This work was supported by the Slovak Research and Development Agency under the Contract no. APVV18-0070.

\section{Authors contributions}

EŠ wrote the text of the manuscript and coordinated work of the co-authors. TB contributed to writing of the text and coordinated performed analyses. JH coordinated fieldwork and proposed design and methods of the study. ST contributed to interpretation of the results and their discussion focusing on clinical aspects of the issue. MT performed analyses and contributed to the interpretation of the results and MS performed analyses and revised the manuscript. HH revised the draft of the manuscript and contributed to interpretation of the public health implications of the issue. All authors read and approved the manuscript.

\section{Acknowledgements}

This work was supported by the Slovak Research and Development Agency under the Contract no. APVV18-0070. 


\section{References}

1. World Health Organization: Oral Health. https://www.who.int/ (2019). Accessed 28 Oct 2019.

2. Sukumaran A, Pradeep SA. Early Childhood Caries: Prevalence, Risk Factors, and Prevention. Front Pediatr. 2017;5:157.

3. Jürgensen N, Petersen PE. Promoting oral health of children through schools - Results from a WHO global survey 2012. Community Dental Health 2013;30:204-218.

4. Petersen PE, Bourgeois D, Ogawa H, Estupinan-Day S, Ndiaye C. The global burden of oral diseases and risks to oral health. Bull World Health Organ. 2005;83:661-9.

5. Tagliaferro EPS, Ambrosano GMB, Meneghim MC, Pereira AC. Risk indicators and risk predictors of dental caries in schoolchildren. J Appl Oral Sci. 2008;16(6):408-413.

6. Hall-Scullin E, Whitehead H, Milsom K, Tickle M, Su TL, Walsh T. Longitudinal Study of caries Development from Childhood to Adolescence. J Dent Res. 2017;96(7):762-767.

7. Li MY, Zhi QH, Zhou Y, Qiu RM, Lin HC. Impact of early childhood caries on oral health-related quality of life of preschool children. Eur J Paediatr Dent. 2015;16(1):65-72.

8. Patel R. The State of Oral Health in Europe. http://www.oralhealthplatform.eu/wpcontent/uploads/2015/09/Report-the-State-of-Oral-Health-in-Europe.pdf (2012). Accessed 10 Sept 2019.

9. Radić M, Benjak T, Vukres VD, Rotim Ž, Zore IF. Presentation of DMFT/dmft Index in Croatia and Europe. Acta Stomatol Croat. 2015;49(4):275-284.

10. Marthaller TM. Changes in dental caries 1953-2003. Caries Res. 2004;38(3):173-81.

11. Zaborskis A, Milciuviene S, Narbutaite J, Bendoraitiene E, Kavaliauskiene A. Caries experience and oral health behaviour among 11 - 13-years-olds: An ecological study of data from 257 European countries, Israel, Canada and USA. Community Dental Health 2010;27:102-8.

12. Dukić W, Delija B, Dukić Caries prevalence among schoolchildren in Zagreb, Croatia. Croat Med J. 2011;52(6):665-671.

13. Moreira RS. Epidemiology of Dental Caries in the World. In: Virdi M, editor. Oral Health Care Pediatric, Research, Epidemiology and Clinical Practices. Intech; 2012. p.149-168.

14. World Health Organization. Future Use of Materials for Dental Restoration. https://www.who.int/oral_health/publications/dental_material_2011.pdf (2010). Accessed 22 Sept 2019.

15. Attin T, Hornecker E. Tooth brushing and oral health: how frequently and when should tooth brushing be performed. Oral Health Prev Dent. 2005;3(3):135-40.

16. Peres MA, Sheiham A, Liu P, Demarco FF, Silva AER, Assunção MC, Menezes AM, Barros FC, Peres KG. Sugar Consumption and Changes in Dental Caries from Childhood to Adolescence. J Dent Res. 2016;95(4):388-394. 
17. Armfield JM, Spencer AJ, Roberts-Thomson KF, Plastow K. Water Fluoridation and the association of sugar-sweetened beverage consumption and dental caries in Australian children. Am J Public Health. 2013;103(3):494-500.

18. Asawa K, Sen N, Bhat N, Tak M, Sultane P, Patil V. Association of sugary foods and drinks consumption with behavioral risk and oral health status of 12- and 15-year-old Indian school children. J Educ Health Promot. 2018;7:19.

19. Bolt-Evelsen K, Vik FN, Stea TH, Klepp KI, Bere E. Consumption of sugar-sweetened beverages and artificially sweetened beverages from childhood to adulthood in relation to socioeconomic status 15 years follow-up in Norway. Int J Behav Nutr Phys Act. 2018;15:8.

20. Abiola Adeniyi A, Eyitope Ogunbodede O, Sonny Jeboda O, Morenike Folayan O. Do maternal factors influence the dental health status of Nigerian pre-school children. Int J Paediatr Dent. 2009;19(6):448-454.

21. Park JB, Han K, Park YG, Ko Y. Association between socioeconomic status and oral health behaviors: The 2008-2010 Korea national health and nutrition examination survey. Exp Ther Med. 2016;12(4):2657-2664.

22. Cianetti S, Lombardo G, Lupatelli E, Rossi G, Abraha I, Pagano S, Paglia L. Dental caries, parents educational level, family income and dental service attendance among children in Italy. Eur $\mathrm{J}$ Paediatr Dent. 2017;18(1):15-18.

23. STATdat Public Database. Vekové zloženie - SR, oblasti, kraje, okresy, mesto, vidiek. [Age distribution -SR, areas, regions, districts, cities, countries.] http://statdat.statistics.sk/cognosext/cgibin/cognos.cgi?b_action=xts.run\&m=portal/cc.xts\&gohome= (2019). Accessed 22 Oct 2019.

24. Jamieson LM, Thomson WM, McGee R. An assessment of the validity and reliability of dental selfreport items used in a National Child Nutrition Survey. Community Dent Oral Epidemiol. 2004;32(1):49-54.

25. Poche C, McCubbrey HM, Munn T. The development of correct toothbrushing technique in preschool children. J Appl Behav Anal. 1982;15(2):315-320.

26. Damle SG, Patil A, Jain S, Damle D, Chopal N. Effectiveness of supervised toothbrushing and oral health education in improving oral hygiene status and practices of urban and rural school children: $\mathrm{A}$ comparative study. J Int Soc of Prev Community Dent. 2014;4(3):175-181.

27. Ahad M, Sukumaran G. Awareness of tooth brushing techniques and proper oral hygiene among school children. J Pharm Sci \& Res. 2015;7(6):367-372.

28. Naseem S, Fatima SH, Ghazanfar H, Haq S, Khan NA, Mehmood M, Ghazanfar A. Oral Hygiene Practices and Teeth Cleaning Techniques Among Medical Students. Cureus. 2017;9(7):1487.

29. Melo P, Fine C, Malone S, Frencken JE, Horn V. The effectiveness of the Brush Day and Night programme in improving children's toothbrushing knowledge and behaviour. Int Dent J. 2018;68:7-16.

30. McGrath C, Bedi R. Gender variations in the social impact of oral health. J Ir Dent Assoc. 2000;46(3):87-91. 
31. Maes L, Vereecken C, Vanobbergen J, Honkala S. Tooth brushing and social characteristics of families in 32 countries. Int Dent J. 2006;56(3): 159-167.

32. Vallejos-Sánchez AA, Medina-Solís CE, Maupóme G, Casanova-Rosado JF, Minaya-Sánchez M, Villalobos-Rodelo JJ, Pontigo-Loyola AP. Sociobehavioural factors influencing toothbrushing frequency among schoolchildren. J Am Dent Assoc. 2008;139(6):743-9.

33. Al-Omiri MK, Al-Wahadni AM, Saeed KN. Oral health attitudes, knowledge, and behaviour among school children in North Jordan. J Dent Educ. 2006;70(2):179-87.

34. Shaghaghian S, Zeraatkar M. Factors Affecting Oral Hygiene and Tooth Brushing in Preschool Children, Shiraz/Iran. J Dent Biomater. 2017;4(2):394-402.

35. Javed F, Feng C, Kopycka-Kedzierawski DT. Incidence of early childhood caries: A systematic review and meta-analysis. J Investig Clin Dent. 2017;8(4).

36. Frencken JE, Sharma P, Stenhouse L, Green D, Laverty D, Dietrich T. Global epidemiology of dental caries and severe periodontitis - a comprehensive review. J Clin Periodontol. 2017;44:94-105.

37. Kostičová M. Ústne zdravie. In: Madarasová Gecková A, editor. Sociálne determinanty zdravia školákov. Košice: Equilibria, s.r.o.; 2019. p. 49-57.

38. Národné Centrum Zdravotníckych Informácií. Štatistické prehl'ady: Zubnolekárska starostlivost' v SR [Statistical Reports: Dental Care in Slovakia]

http://www.nczisk.sk/Documents/publikacie/2017/sp1803.pdf (2017). Accessed 29 Sept 2019.

\section{Figures}

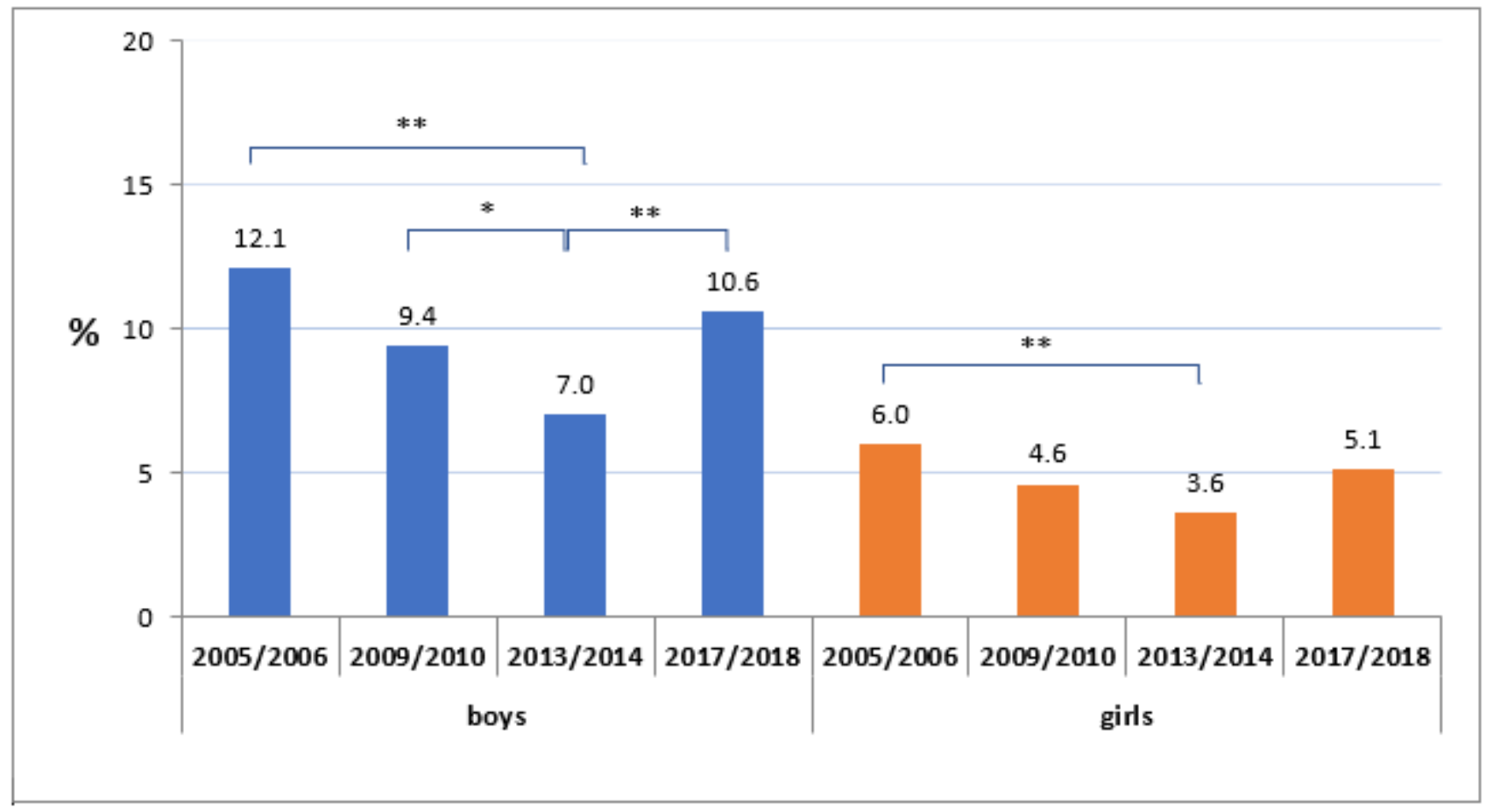

\section{Figure 1}


Teeth brushing less than once a day. Significant differences are marked as ${ }^{*} p<0.05$ and ${ }^{* *} p<0.001$.

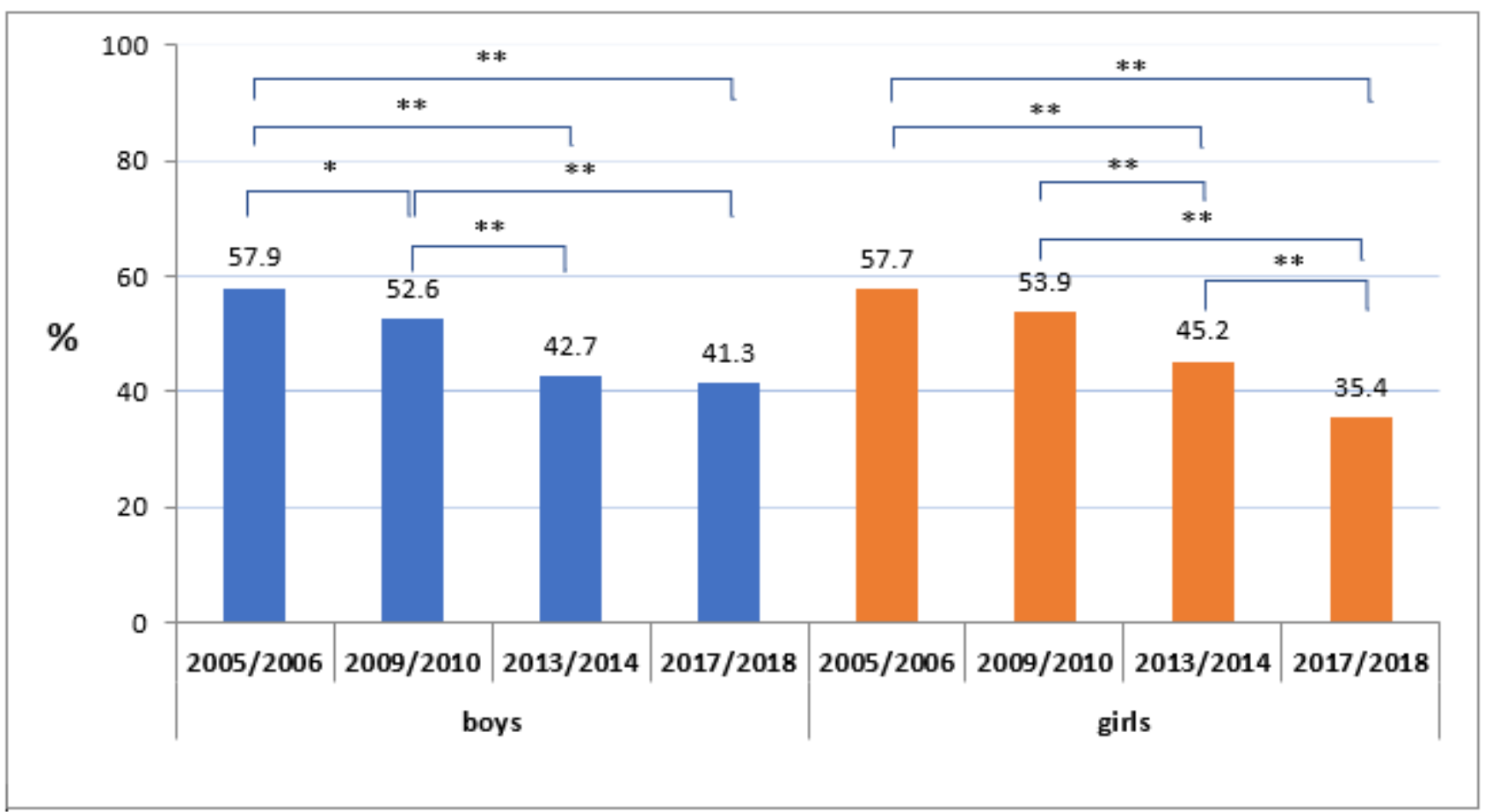

\section{Figure 2}

Consumption of sweets or sweetened soft drinks. Significant differences are marked as ${ }^{*} p<0.05$ and $\star * p<0.001$.

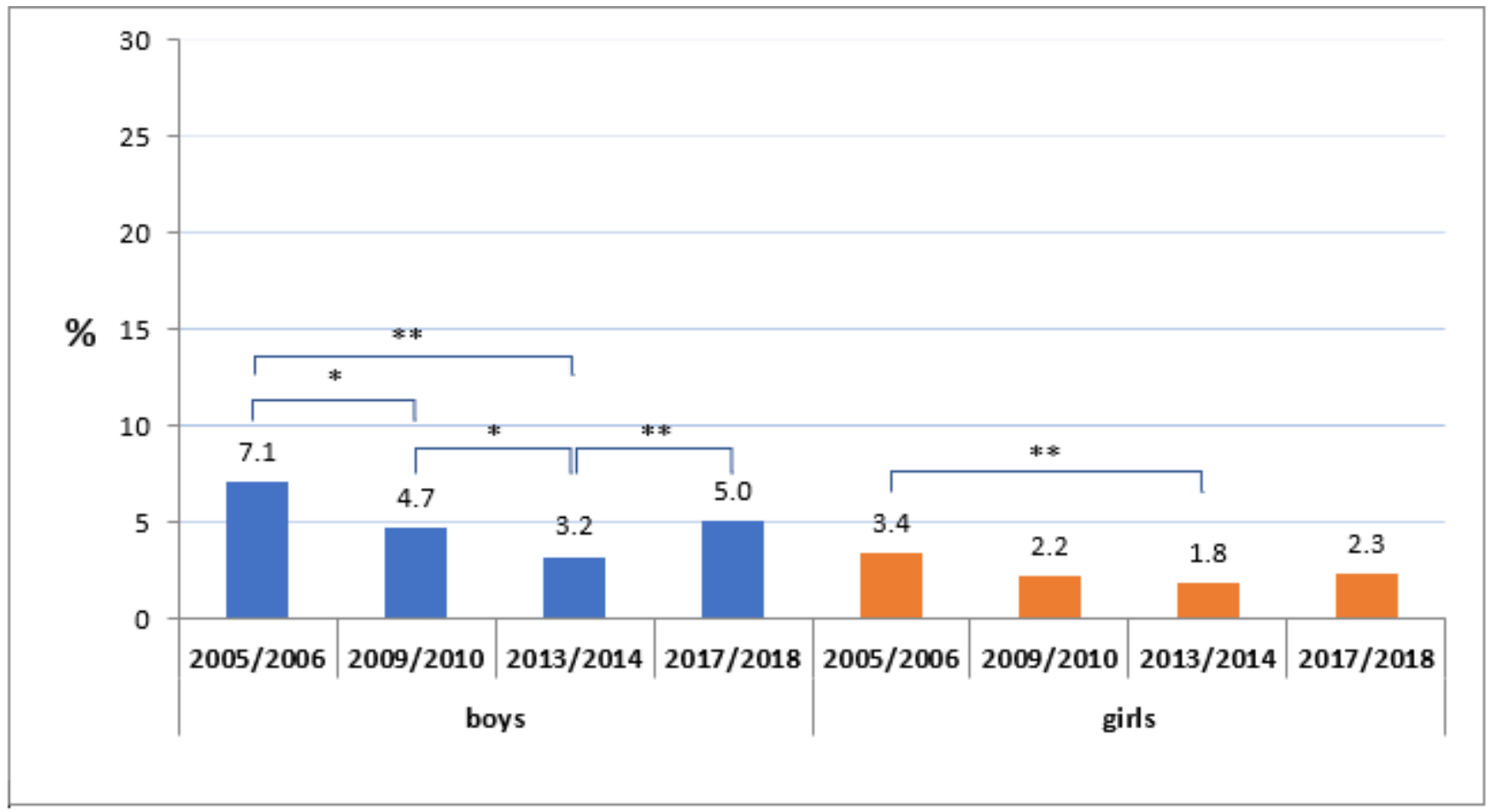

Figure 3 
Teeth brushing less than once a day and consumption of sweets or sweetened soft drinks. Significant differences are marked as ${ }^{*} \mathrm{p}<0.05$ and ${ }^{* *} \mathrm{p}<0.001$.

\section{Supplementary Files}

This is a list of supplementary files associated with this preprint. Click to download.

- STROBEchecklistv4combined.doc 